University of Thi-Qar Journal Vol.13 No. 2 June 2018

Web Site: https://jutq.utq.edu.iq/index.php/main

Email: journal@jutq.utq.edu.iq

\title{
Current modulation by using dual color quantum cascade
}

laser

*Hussein H. Warid

Mohammed Awad hussein

hussein.hadi@sci.utq.edu.iq

haider.r_bio@sci.utq.edu.iq

*Physics Department, Faculty of sciences, University of

Thi-Qar, Al-Nasiriya, Iraq.

\section{Abstract}

Mathematical model to describe electrons and photons in dual color quantum cascade lasers has been proposed. These lasers have the ability to generate laser light in micrometer scale. The model consists of six differential equation for describing change concentration of electrons and photons with time . two of those equations express the first and second wave length photons . the rest equations show electron movement in four electronic levels . then equations to modulate injected current in active region have been employed by using sine function and photons demonstrate electrons variety with time effect of number of gain region, modulation frequency, continuous injection current, alternative injection current on electrons and photons distribution in active region have been studied. The results pointedout increasing in electrons and photons number as the continuous current and gain region number increase as compared with increasing in its number as the alternative current increase.

One can observed distribution of electrons in the second electronic level with increasing number of gain regions does not change .one can conclude in fluency number of gain regions on this region is weak . the results denoted to change in electrons and photons distribution as the frequency modulation change 


\section{University of Thi-Qar Journal Vol.13 No. 2 June 2018 \\ Web Site: https://jutq.utq.edu.iq/index.php/main \\ Email: journal@jutq.utq.edu.iq}

الخلاصة

في هذه الدراسة نم اقتر اح نموذج رياضي لوصف حركة الالكترونات والفونونات في

الليزرات الكمية المتعاقبة ثنائية اللون. هذه الليزرات تمنلك القدرة على توليد ضوء ليزر ضمن

قيم المايكرو متر ـ يتألف النموذج من ستة معادلات تفاضلية لوصف تنغير الالكترونات

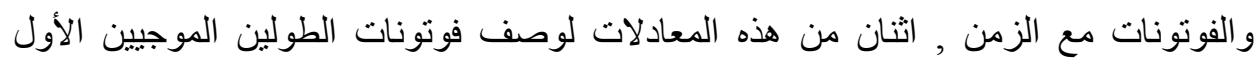

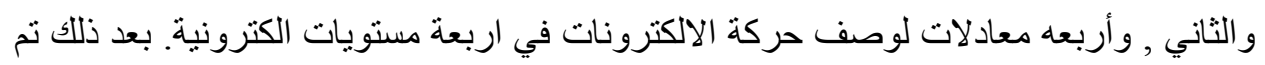

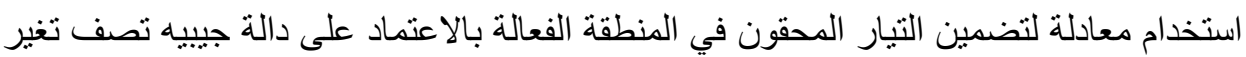

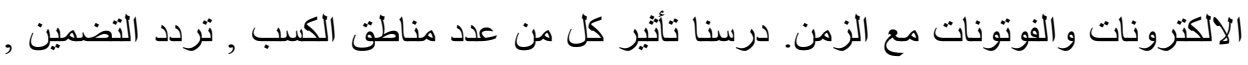

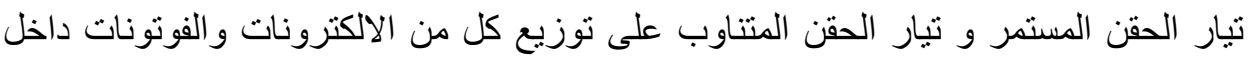

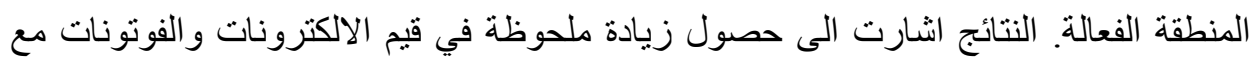

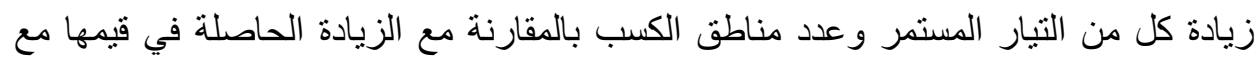
زيادة التيار المتناوب. لاحظنا ثبات توزيع الإلكترونات في المستوي الالكتروني الثاني مع زيادة عدد مناطق الكسب مما يدلل على ضعف تأثثير عدد مناطق الكسب على هذه المنطقة. ايضا النتائج اشارت الى وجود تغيير في توزيع الالكترونات و الفونونات مع تغير تردد التضمين.

Keywords: Dual-color quantum cascade lasers, rate equations model, current modulation.

\section{Introduction}

Quantum laser, a new generation of semiconductor lasers, has been obtained because of the development of semiconductor lasers. A major development in semiconductor lasers has been that a new generation of semiconductor lasers, known as quantum sequential laser. Intersubband semiconductor lasers offer opportunities for obtaining compact laser sources with emission wavelengths in the mid-infrared to far-infrared range [1]. It can achieve pulsed room temperature operation and operate in continuous mode up to $150 \mathrm{~K}$ [2]. This laser was developed to operate at the terahertz frequency. structures with multi-peaked gain spectra and associated multiple-wavelength emission (multicolor operation) have 
Web Site: https://jutq.utq.edu.iq/index.php/main

Email: journal@jutq.utq.edu.iq

already been achieved by direct generation $[3,4]$ or by nonlinear optics $[5,6]$ in the mid-IR spectral region .

The second-harmonic generation (SHG) in quantum-cascade lasers can be a favorable way to access the multi-wavelength operation in midinfrared region [7]. civilian applications such as laser radar, secure optical communication, remote chemical sensing, pollution monitoring, molecular spectroscopy, medical care, and infrared countermeasures[8]. The work on Quantum cascade lasers is based on the transitions in intersubband in semiconductor multi- quantum wells structure heterostructures For this reason, it became desirable in many applications Since only one charge carrier species is involved in the lasing process the devices are also termed 'unipolar semiconductor lasers.

In this paper, we study the dynamics of dual-color lasers as shown in Fig. (1). In Figure 1, One can observe the movement of the carriers in conduction band of Quantum cascade lasers where the carriers are injected to the secondary levels of the in conduction band by the injection current as well as observe all transitions between these levels, in addition to times of these transitions as shown in Figure. in the upper well The carriers of the upper level $(n=4)$ move into the lower level $(n=3)$ of the in same well and the first wavelength is emitted

after that, The carriers move into the upper level $(n=2)$ in the in lowest well and move towards the lower level in same well emitting second wavelength It then moves to region $i$, which refers to the injection region, which re-injects the electrons to level 4 in the next gain region through the tunneling. The wavelength in this laser does not depend on the energy gap as in traditional semiconductor lasers but depends on the thickness of quantum wells that component of this device. The operation of these lasers depends on the current injected into the active region. 


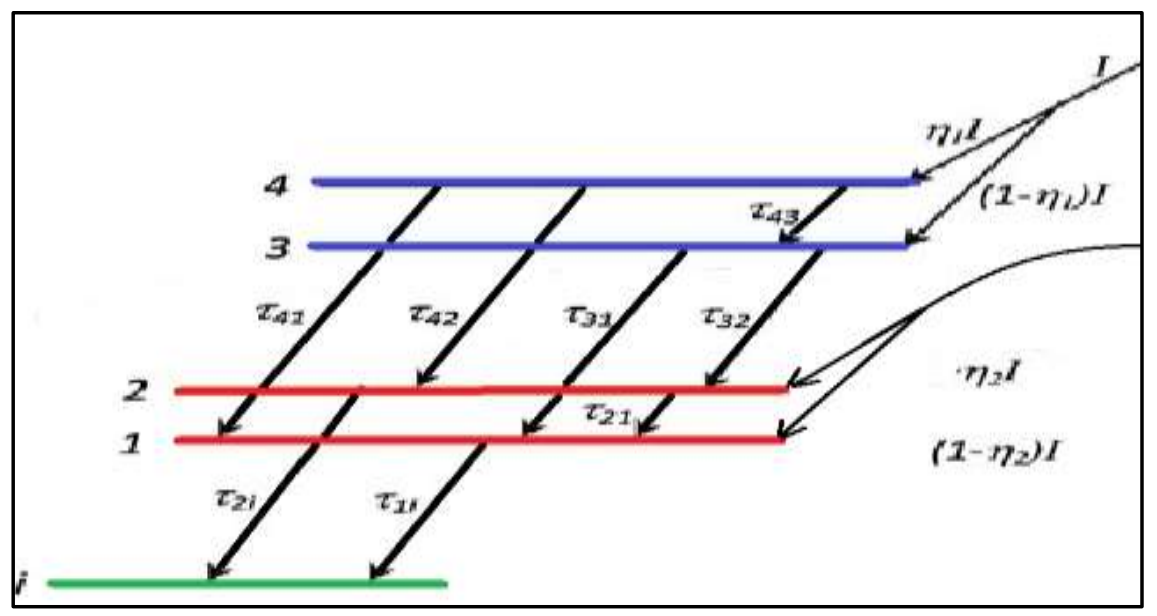

Fig (1): A simple schematic of level diagram and various transition lifetimes to describe the rate equation analysis of a five level QCL. 4, 3, 2 and 1 denote the radiative levels, $i$ is the injector state, $I$ is the injected current, $\eta_{1}$ and $\eta_{2}$ are injection efficiencies and $\tau_{41}, \tau_{32}, \tau_{31}$ , $\tau_{21}, \tau_{2 \mathrm{i}}$ and $\tau_{1 \mathrm{i}}$ are the lifetimes due to nonradiative transitions $4 \rightarrow 3$, $4 \rightarrow 2,4 \rightarrow 1,3 \rightarrow 2,3 \rightarrow 1,2 \rightarrow 1,1$ to Injection reigns $i$, respectively[9] .

Since there is no light laser produced from the device unless the injected current exceeds the threshold current value. After the current exceeds the value of the threshold current, it produces the population inversion, which leads to gain and production of output light. Therefore, the power laser increases linearly with a maximum value of current. It is clear from this correlation between the current and the power that it can be used to convert information from electrical to light if we make the current change with the change of data and this is why laser information is included. Obviously this interdependence between the current and the power that it can be used to convert information from electrical to light if we make the current changes with change of data, that is known as information modulation by laser. The modulation velocity of the semiconductor laser is not limited to the lifetime of electron emission in the active region of the laser. This is due to the fact that there is a strong coupling between the density of carriers and output power. 
Web Site: https://jutq.utq.edu.iq/index.php/main

Email: journal@jutq.utq.edu.iq

In [10], it is found that unipolar lasers have the potential for achieving terahertz dc modulation bandwidths. The effect of both the relevant carrier and tunneling lifetimes for a prototype triple quantum well structure on the modulation response have been investigated through self-consistent rate equation analysis in [11]. The results showed that there was a relationship between the modulation bandwidth and the laser output power. The maximum frequency of the modulation does not increase consistently with the increase of the optical output power, and the modulation response frequency can be obtained by using device design parameters that result in reduced photon lifetime. In this paper, we present an analysis of the results associated with the study of the properties of the current modulation with Quantum cascade lasers, which was studied by the rate equation model. We will talk about the impact of Quantum cascade lasers dynamics under the influence of a change in the several parameters that appear in the mathematical model that describes this device.

The kinetic dynamics of the Quantum cascade lasers were studied by using a mathematical model that describes the dynamics of both the vector count in the upper molecular band and the number of oscillating photons in the laser. A four-level model of this laser was taken to reduce complexity in this study. This rate equation model is composed of six equations, four of which relate to the change's time of the number of carriers in the four quantitative levels, two of which are for the change's time of the number of photons. We will present the mathematical model of these lasers in the second section of this paper. Section III presents the results of the research, while presenting the main conclusions in section IV.

\section{Modal}

To understand and analyze the kinetic dynamics of the carriers and the emission of photons in the two-color quantum cascade lasers shown in Figure 1, a mathematical model describing this device should be developed. This model is a set of rate equations. This requires consideration of each of the active reign, injection reign and injector of 


\section{University of Thi-Qar Journal Vol.13 No. 2 June 2018 \\ Web Site: https://jutq.utq.edu.iq/index.php/main \\ Email: journal@jutq.utq.edu.iq}

the device under study, which requires a model consisting of a large number of rate equations, and it is known that dealing with so many rate equations is complicated. In order to reduce this complexity, a four-level model is applied here in an active reign containing from Two coupling wells Take into consideration account the lifetime of the carriers taking into account the removal of the conjugated carriers from other levels. The rate equations model for the active reign is described in the following equations $[12,13]$ :

$$
\begin{gathered}
\frac{d n_{4}}{d t}=\frac{\eta_{1} I}{e}-\frac{n_{4}}{\tau_{41}}-\frac{n_{4}}{\tau_{43}}-\frac{n_{4}}{\tau_{42}}-\frac{n_{4}}{\tau_{s p 1}}-G_{1}\left(n_{4}-n_{3}\right) n_{p h 1} \\
-G_{2}\left(n_{4}\right. \\
\left.-n_{3}\right) n_{p h 2}
\end{gathered}
$$

$$
\begin{gathered}
\frac{d n_{3}}{d t}=\frac{\left(1-\eta_{1}\right) I}{e}-\frac{n_{3}}{\tau_{32}}-\frac{n_{3}}{\tau_{31}}-\frac{n_{4}}{\tau_{43}}-\frac{n_{4}}{\tau_{s p 1}}+G_{1}\left(n_{4}-n_{3}\right) n_{p h 1} \\
+G_{2}\left(n_{4}\right. \\
\left.-n_{3}\right) n_{p h 2}
\end{gathered}
$$

$$
\begin{aligned}
\frac{d n_{2}}{d t}=\frac{\eta_{2} I}{e}- & \frac{n_{2}}{\tau_{21}}-\frac{n_{2}}{\tau_{2 i}}+\frac{n_{4}}{\tau_{42}}-\frac{n_{3}}{\tau_{32}}-\frac{n_{2}}{\tau_{s p 2}}-G_{1}\left(n_{2}-n_{1}\right) n_{p h 1} \\
& -G_{2}\left(n_{2}\right. \\
& \left.-n_{1}\right) n_{p h 2}
\end{aligned}
$$

$$
\begin{gathered}
\frac{d n_{1}}{d t}=\frac{\left(1-\eta_{2}\right) I}{e}-\frac{n_{1}}{\tau_{1 i}}+\frac{n_{4}}{\tau_{41}}+\frac{n_{2}}{\tau_{21}}+\frac{n_{3}}{\tau_{31}}+\frac{n_{2}}{\tau_{s p 2}}+G_{1}\left(n_{2}-n_{1}\right) n_{p h 1} \\
+G_{2}\left(n_{2}\right. \\
\left.-n_{1}\right) n_{p h 2}
\end{gathered}
$$

$$
\begin{gathered}
\frac{d n_{p h 1}}{d t}=N_{p} G_{1}\left(n_{4}-n_{3}\right) n_{p h 1}+N_{p} G_{2}\left(n_{2}-n_{1}\right) n_{p h 2} \\
-\frac{n_{p h 1}}{\tau_{p h 1}}
\end{gathered}
$$




$$
\begin{gathered}
\frac{d n_{p h 2}}{d t}=N_{p} G_{1}\left(n_{4}-n_{3}\right) n_{p h 1}+N_{p} G_{2}\left(n_{2}-n_{1}\right) n_{p h 2} \\
-\frac{n_{p h 2}}{\tau_{p h 2}}
\end{gathered}
$$

In the above equations, $\mathrm{n} 1, \mathrm{n} 2, \mathrm{n} 3$ and $\mathrm{n} 4$ are the electron populations in the subbands in the four levels (the figures below refer to level 3 and level 4 in the first well, level 2 and level 1 in the second well). $n_{\mathrm{ph} 2}$ and $n_{\mathrm{ph} 1}$ The number of photons for the first and second wavelengths, respectively ,$\eta_{1}$ and $\eta_{2}$ the injection current coefficients are applied. I is the injection current. $\mathrm{e}$ is an electron charge. $\mathrm{N}_{\mathrm{p}}$ is the number of stages of laser gain $\left(\mathrm{n}_{2}-\mathrm{n}_{1}\right)$ and $\left(\mathrm{n}_{4}-\mathrm{n}_{3}\right)$ population inversion in first and second quantum well, respectively.$\tau_{\mathrm{sp} 1}$ and $\tau_{\mathrm{sp} 2}$ are the spontaneous emission lifetime for the first and second wavelengths, $\tau_{11}, \tau_{21}, \tau_{31}, \tau_{32}, \tau_{41}, \tau_{42}$ Is the time to transition from level $4 \rightarrow 3,4 \rightarrow 2,4 \rightarrow 1,3 \rightarrow 2,3 \rightarrow 1,2 \rightarrow 1,1$ to Injection reigns $I$, respectively. $G_{1}$ and $G_{2}$ The gain coefficients for the first and second wavelengths can be expressed as[12]:

$$
\begin{aligned}
& \mathrm{G}_{1} \\
& =\frac{4 \pi e^{2} Z_{43}^{2} \Gamma v_{g}}{V \varepsilon_{0} n_{e f f} \lambda_{43}\left(2 \gamma_{43}\right)} \\
& \mathrm{G}_{2} \\
& =\frac{4 \pi e^{2} Z_{21}^{2} \Gamma v_{g}}{V \varepsilon_{0} n_{e f f} \lambda_{21}\left(2 \gamma_{21}\right)}
\end{aligned}
$$

$\Gamma$ confinement factor of light.$v_{g}$ Is the phase velocity. $V$ is the volume of the active region. $\lambda_{43}$ and $\lambda_{21}$ the first and second wavelengths ,respectively . $2 \gamma_{43}$ and $2 \gamma_{21}$ is the full-width at half-maximum (FWHM) of the intersubband electroluminescence. $\mathrm{Z}_{43}$ and $\mathrm{Z}_{21}$ is the dipole matrix 


\section{University of Thi-Qar Journal Vol.13 No. 2 June 2018}

Web Site: https://jutq.utq.edu.iq/index.php/main

Email: journal@jutq.utq.edu.iq

element between the coupled levels. $\tau_{\mathrm{ph} 1}$ and $\tau_{\mathrm{ph} 2}$ is the photon lifetime in the laser cavity, can be expressed as[12]:

$\frac{1}{\tau_{\mathrm{ph} 1,2}}$
$=\frac{\mathrm{c}\left(\alpha_{\mathrm{w} 1,2}+\alpha_{\mathrm{m}}\right)}{\mathrm{n}_{\mathrm{eff}}}$

Where $\mathrm{C}$ is the speed of light . $\alpha_{\mathrm{w} 1,2}$ waveguide losses for two wave lengths.$\alpha_{\mathrm{m}}$ Is the loss of the active reign .for Calculates the steady state value for the concentration of the carriers, $\mathrm{n}_{1}, \mathrm{n}_{2}, \mathrm{n}_{3}$ and $\mathrm{n}_{4}$, and number of photons $\mathrm{n}_{\mathrm{ph} 1}$ and $\mathrm{n}_{\mathrm{ph} 2}$, We make the left side in the rate equations equal to zero as follows:

$\mathrm{n}_{40}$

$=\frac{\frac{\eta_{1} \mathrm{I}}{\mathrm{e}}+\mathrm{G}_{1} \mathrm{n}_{30} \mathrm{n}_{\mathrm{ph} 10}+\mathrm{G}_{2} \mathrm{n}_{30} \mathrm{n}_{\mathrm{ph} 20}}{\frac{1}{\tau_{41}}+\frac{1}{\tau_{43}}+\frac{1}{\tau_{42}}+\frac{1}{\tau_{\mathrm{sp} 1}}+\mathrm{G}_{1} \mathrm{n}_{\mathrm{ph} 10}+\mathrm{G}_{2} \mathrm{n}_{\mathrm{ph} 20}}$

$\mathrm{n}_{30}$

$=\frac{\frac{\left(1-\eta_{1}\right) I}{e}-\frac{n_{40}}{\tau_{43}}-\frac{n_{40}}{\tau_{s p 1}}+G_{1} n_{40} n_{p h 10}+G_{2} n_{40} n_{p h 20}}{\frac{1}{\tau_{32}}+\frac{1}{\tau_{31}}+G_{1} n_{p h 10}+G_{2} n_{p h 20}}$

$\mathrm{n}_{20}$

$=\frac{\frac{\eta_{2} \mathrm{I}}{\mathrm{e}}+\frac{\mathrm{n}_{40}}{\tau_{42}}-\frac{\mathrm{n}_{30}}{\tau_{32}}+G_{1} \mathrm{n}_{10} \mathrm{n}_{\mathrm{ph} 10}+\mathrm{G}_{2} \mathrm{n}_{10} \mathrm{n}_{\mathrm{ph} 20}}{\frac{1}{\tau_{21}}+\frac{1}{\tau_{2 \mathrm{i}}}+\frac{1}{\tau_{\mathrm{sp} 2}}+\mathrm{G}_{1} \mathrm{n}_{\mathrm{ph} 10}+\mathrm{G}_{2} \mathrm{n}_{\mathrm{ph} 20}}$

$\mathrm{n}_{10}=\frac{\frac{\left(1-\eta_{2}\right) \mathrm{I}}{\mathrm{e}}+\frac{\mathrm{n}_{40}}{\tau_{41}}+\frac{\mathrm{n}_{20}}{\tau_{21}}+\frac{\mathrm{n}_{30}}{\tau_{31}}+\frac{\mathrm{n}_{20}}{\tau_{\mathrm{sp} 2}}+\mathrm{G}_{1} \mathrm{n}_{20} \mathrm{n}_{\mathrm{ph} 10}+\mathrm{G}_{2} \mathrm{n}_{20} \mathrm{n}_{\mathrm{ph} 20}}{\frac{1}{\tau_{1 \mathrm{i}}}+\mathrm{G}_{1} \mathrm{n}_{\mathrm{ph} 10}+\mathrm{G}_{2} \mathrm{n}_{\mathrm{ph} 20}}$ 
$\mathrm{n}_{\mathrm{ph} 10}$

$$
=\frac{-\mathrm{N}_{\mathrm{p}} \mathrm{G}_{2}\left(\mathrm{n}_{20}-\mathrm{n}_{10}\right) \mathrm{n}_{\mathrm{ph} 20}}{\mathrm{~N}_{\mathrm{p}} \mathrm{G}_{1}\left(\mathrm{n}_{40}-\mathrm{n}_{30}\right)-\frac{1}{\tau_{\mathrm{ph} 1}}}
$$

$$
=\frac{\mathrm{n}_{\mathrm{ph} 20}}{\mathrm{~N}_{\mathrm{p}} \mathrm{G}_{2}\left(\mathrm{n}_{20}-\mathrm{n}_{10}\right) \mathrm{n}_{\mathrm{ph} 20}-\frac{\mathrm{n}_{\mathrm{ph} 20}}{\tau_{\mathrm{ph} 2}}}
$$

The output power of the semiconductor laser depends on the current injected for the effective region of this device ,The population inversion of this device obtains when the injected current is higher than the threshold current. It is well known in the field of the use of semiconductor lasers that the output power of lasers depends on the injected current into the active region .After the injected current exceeds the threshold limit, the population inversion resulting that leads to gain and production of light so that the output power laser is increased linearly with a maximum value of current. This correlation between the current and the power it can be used in converting the electricity information to light information if we make the current changes similar that the data changes. for study the dynamics of dual-color lasers with direct modulation of current We use the Eq. (16) to express the current in the rate equations where the current is found in these equations:

$\mathrm{I}(\mathrm{t})$

$=\mathrm{I}_{0}+\mathrm{I}_{\mathrm{ac}} \sin (\omega \mathrm{t})$

Since $\mathrm{I}_{0}$ is the continuous part of the current $\mathrm{I}_{\mathrm{ac}}$ is the alternating part of the current and $\omega$ is the modulated frequency.

\section{Results and discussion}

Fig (2)-(7) represent the changes of the carriers and photons in the quantum cascade laser with time when the current modulation is found at different values of the the continuous part of current. 


\section{University of Thi-Qar Journal Vol.13 No. 2 June 2018 \\ Web Site: https://jutq.utq.edu.iq/index.php/main \\ Email: journal@jutq.utq.edu.iq}

One can observe from all shapes that there is an increase in the number of carriers and photons with increasing continuous current $\mathbf{I}_{\mathbf{D C}}$ which refers to the increase in carriers caused by the increase continuous current $\mathbf{I}_{\mathbf{D C}}$. We observe from Fig (2) the periodic behavior of the increase in the carriers caused by the sinusoidal function in the current modulation equation. For all these shapes, when a curve is magnified, the values are not equal For both the peak or the bottom. This indicates the contributions of the losses in these results. We also note that there is a succession in the values of photons where we note that the number of photons of the second wavelength has increased compared to the number of photons of the first wavelength, although the first wavelength was the largest when increasing the current and the number of stages.

This can be explained by the satisfaction of the gain, since when the gain is satisfied because of the increasing number of photons due to their generation speed, the gain decreases and we see an increase in the number of photons of the second wavelength and observed that when all the variables are stable and the frequency change is included we get the same values of the photons and the two wavelengths.

The Fig (8)-(13) are represented behavior of time for the changes of the carriers number and photons number by increasing the alternating part of the current when the current modulation is found. In general, one can observe an increase in all curves due to the contribution of the alternating current in increasing the carriers within the active region. The increase of carriers within the active region is the reason for the change of the refractive index and thus with the line width enhancement factor(LEF) As the carriers change, this factor may increase or decrease. although most studies point to the small factor in this type of lasers, it can be increased through processes that ensure the increase amount of carriers within the region .In this research, according to the values used, we expect that there is no significant change in this factor, since the increases in the carriers are of the same order.

Fig (14)-(19) shows Effect of increasing the gain stages on the temporal change of the carriers and photons with the current modulation. In general, increasing the number of gain stages means increasing the number of carriers and photons in the active region. This factor is 


\section{University of Thi-Qar Journal Vol.13 No. 2 June 2018 \\ Web Site: https://jutq.utq.edu.iq/index.php/main \\ Email: journal@jutq.utq.edu.iq}

important in terms of physical and dynamic properties as shown in some previous studies. Although the increase in the number of gain stages causes an increase in photons generated because same of electron emits multiple photons and reduces injection current, it also increases the probability of spontaneous emission and absorption of photons in active region, We also notice from the shapes that there is a slight divergence between the curves of change of carriers in the first four forms and overlap and converge at high values, but in the forms of photons we notice that there is a clear differentiation between the curves and a significant expansion of the resulting values.Also note that each curve in the forms begins to widen with an increase the value of the number gain stages, we mean here the distance between the highest value and the lowest value. This is because when the number of gain stages are increases the number of photons generated in the active region is increases also,

Since the number of gain stages is part of the calculation the values of the steady state, this will increase the initial value of the photons at the start of the implementation calculations. This expansion is due to the large value of the number of photons at the large values of the number of gain stages compared to the small values of photons at the small values of the carriers number. So this difference in breadth we see it when we draw it together .

The last forms represent the change of carriers with time when there is a current modulation of different values for the frequency modulation.

There we chose values ranging from $5 \mathrm{GHz}$ to $20 \mathrm{GHz}$ and these values are small with these lasers operating within the of terahertz range.

We observe through the forms that the cyclic pattern is produced from the sinusoidal periodicity but the number increases with increasing frequency. We do not notice any increase in the number of carriers or photons because all the variables are stable, the most important both continuous and alternating current. response of these lasers refers to the non-linear properties that characterize these lasers . There are Some researches is published and the other searches are not yet published this researches, for of nonlinear properties and nutrition optical response or negative nutrition electro optical for this lasers or by lock injection. refer the change 


\section{University of Thi-Qar Journal Vol.13 No. 2 June 2018 \\ Web Site: https://jutq.utq.edu.iq/index.php/main \\ Email: journal@jutq.utq.edu.iq}

frequency respond in the final shapes to be this laser behavior as like as other lasers semiconductor under the influence of operations the above .The values used in this search are shown in the table below.

This table shows the values used in this search

\begin{tabular}{|c|c|c|}
\hline الرمز & القيمة & الوحدة \\
\hline$\tau_{\mathrm{i} 4}$ & 0.3 & ps \\
\hline$\tau_{\mathrm{i} 3}$ & 1.96 & ps \\
\hline$\tau_{43}$ & 0.24 & ps \\
\hline$\tau_{42}$ & 41 & ps \\
\hline$\tau_{32}$ & 0.14 & ps \\
\hline$\tau_{31}$ & 12 & ps \\
\hline$\tau_{21}$ & 0.23 & ps \\
\hline$\tau_{2 \mathrm{i}}$ & 7 & ps \\
\hline$\tau_{1 \mathrm{i}}$ & 0.96 & ps \\
\hline$\eta$ & 1 & - \\
\hline$\eta_{1}$ & 0.91 & - \\
\hline$\eta_{2}$ & 0.98 & - \\
\hline$z_{21}$ & 1.09 & $\mathrm{~nm}$ \\
\hline$z_{43}$ & 0.88 & $\mathrm{~nm}$ \\
\hline$J_{\text {th1 }}$ & 0.98 & $\mathrm{KA} / \mathrm{cm}^{2}$ \\
\hline$J_{\text {th2 }}$ & 0.58 & $\mathrm{KA} / \mathrm{cm}^{2}$ \\
\hline$I_{\text {th1 }}$ & 197 & $m A$ \\
\hline$I_{\text {th2 }}$ & 116 & $m A$ \\
\hline$N_{\mathrm{P}}$ & 50 & - \\
\hline$\gamma_{43}$ & 3 & mev \\
\hline$\gamma_{21}$ & 3.2 & mev \\
\hline$\alpha_{\mathrm{m}}$ & 10 & $\mathrm{~cm}^{-1}$ \\
\hline$\alpha_{\mathrm{w} 1}$ & 20 & $\mathrm{~cm}^{-1}$ \\
\hline$\alpha_{\mathrm{w} 2}$ & 25 & $\mathrm{~cm}^{-1}$ \\
\hline
\end{tabular}


University of Thi-Qar Journal Vol.13 No. 2 June 2018

Web Site: https://jutq.utq.edu.iq/index.php/main

Email: journal@jutq.utq.edu.iq

\begin{tabular}{l|l|c}
\hline$n_{\text {eff }}$ & 2.22 & - \\
\hline$n_{\text {eff1 }}$ & 2.22 & - \\
\hline$n_{\text {eff2 }}$ & 2.22 & - \\
\hline$\lambda_{1}$ & 33 & $\mu m$ \\
\hline$\lambda_{2}$ & 52 & $\mu m$
\end{tabular}

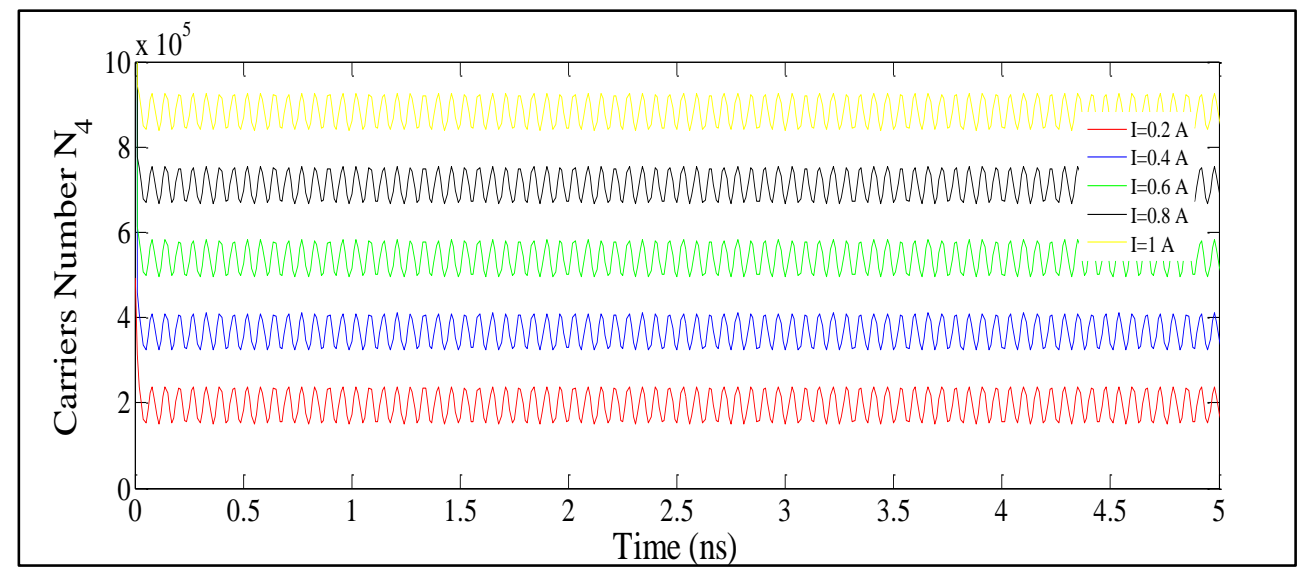

Fig (2): The time variation of the carriers N4 in the process current modulation with different values of the continuous current .

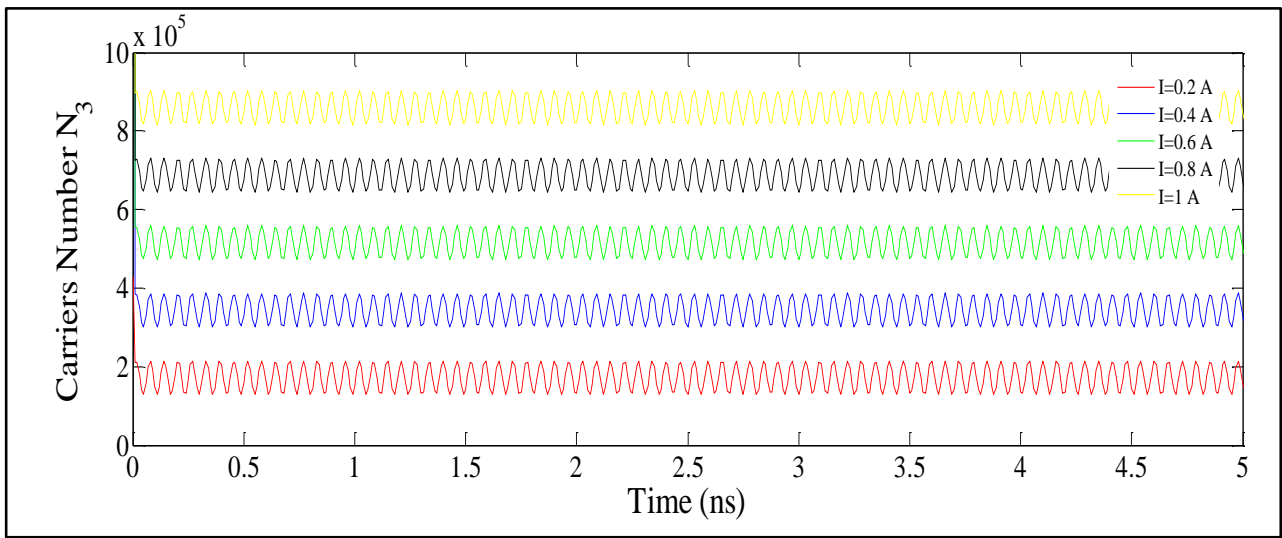

Fig (3): The time variation of the carriers N3 in the process current modulation with different values of the continuous current. 
University of Thi-Qar Journal Vol.13 No. 2 June 2018

Web Site: https://jutq.utq.edu.iq/index.php/main

Email: journal@jutq.utq.edu.iq

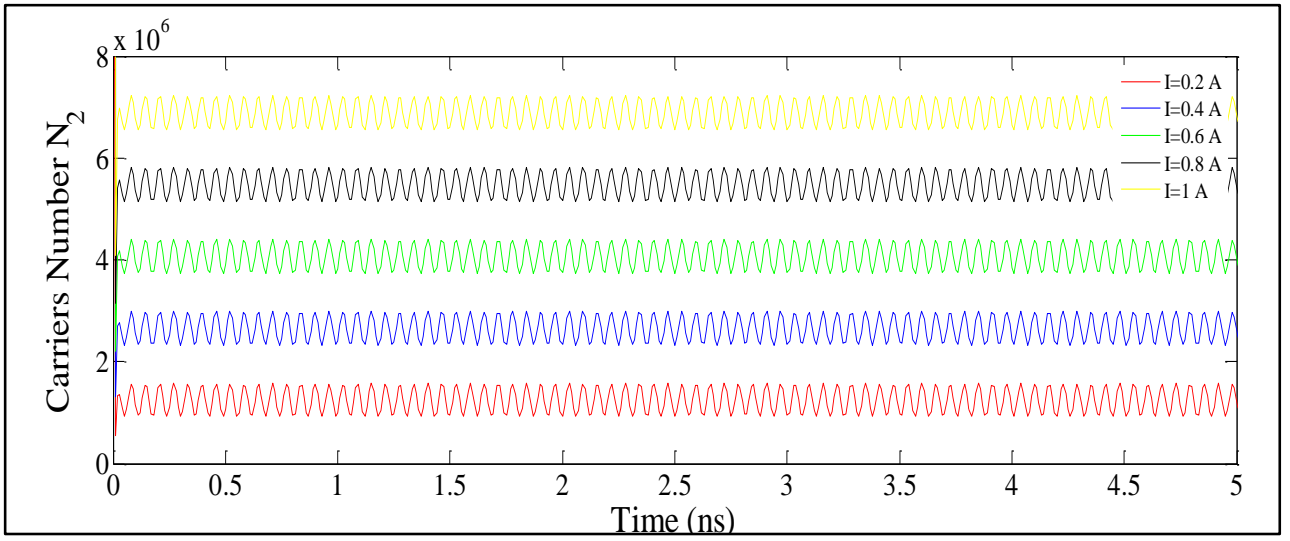

Fig (4): The time variation of the carriers N2 in the process current modulation with different values of the continuous current.

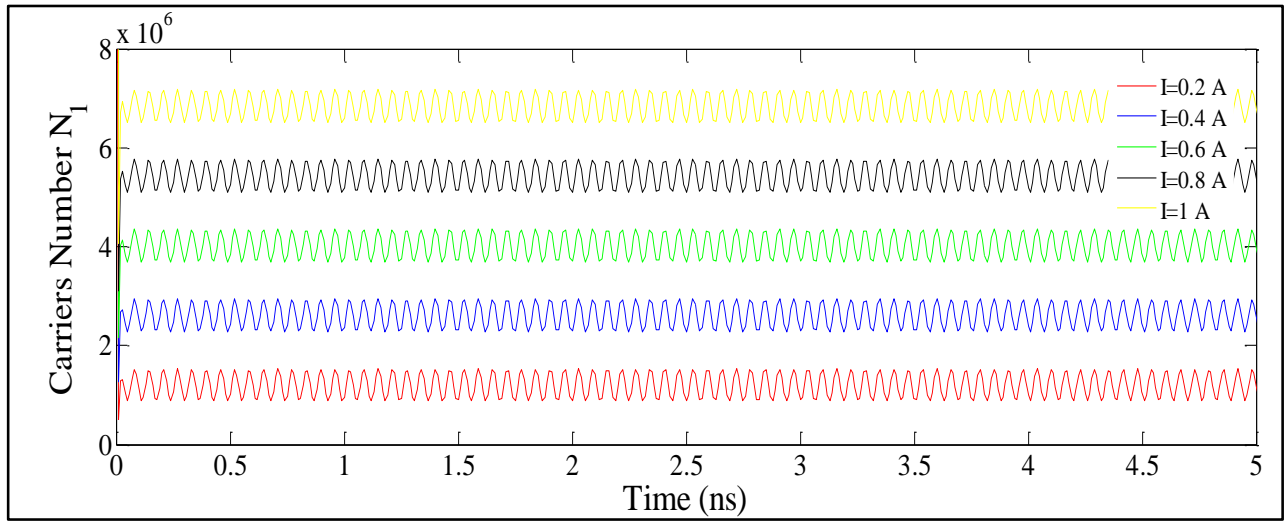

Fig (5): The time variation of the carriers $\mathrm{N} 1$ in the process current modulation with different values of the continuous current. 
University of Thi-Qar Journal Vol.13 No. 2 June 2018 Web Site: https://jutq.utq.edu.iq/index.php/main

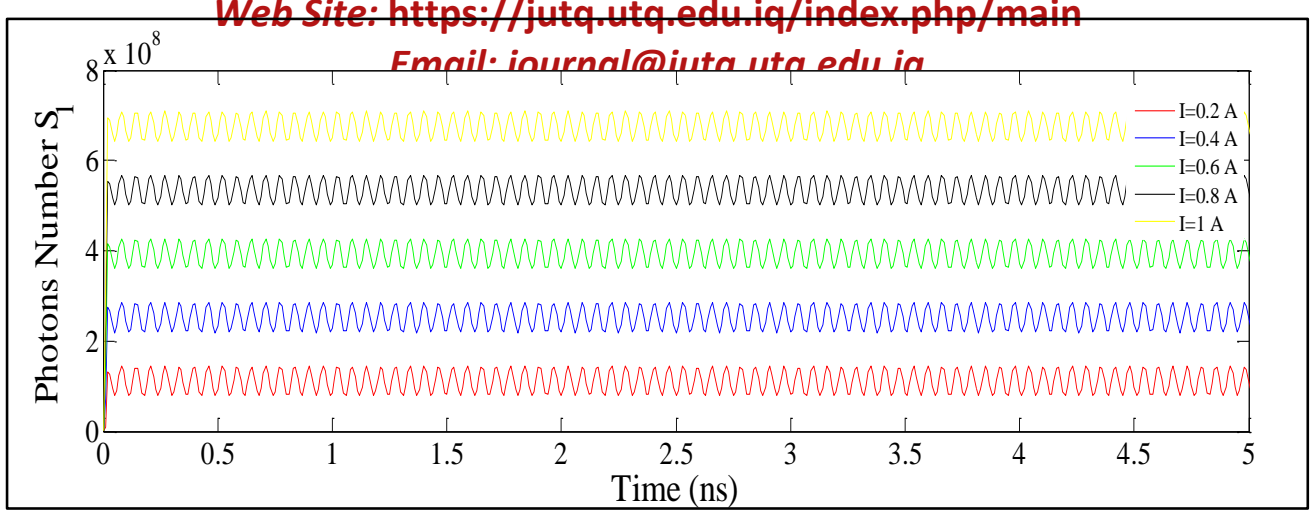

Fig (6): The time variation of photons S1 in the current modulation process with different values of the continuous current.

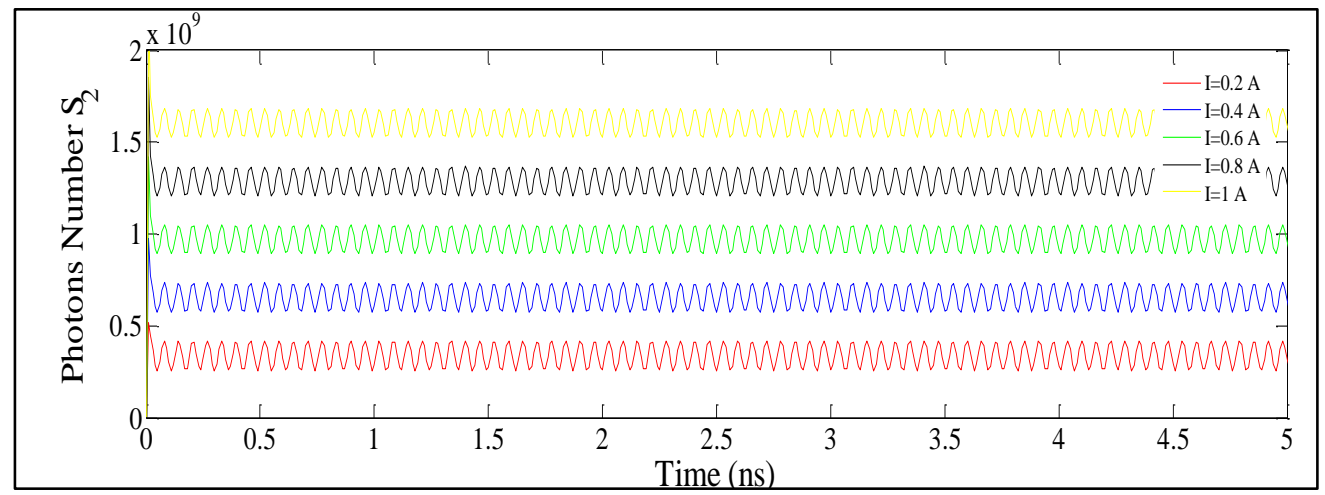

Fig (7): The time variation of photons $S 2$ in the current modulation process with different values of the continuous current.

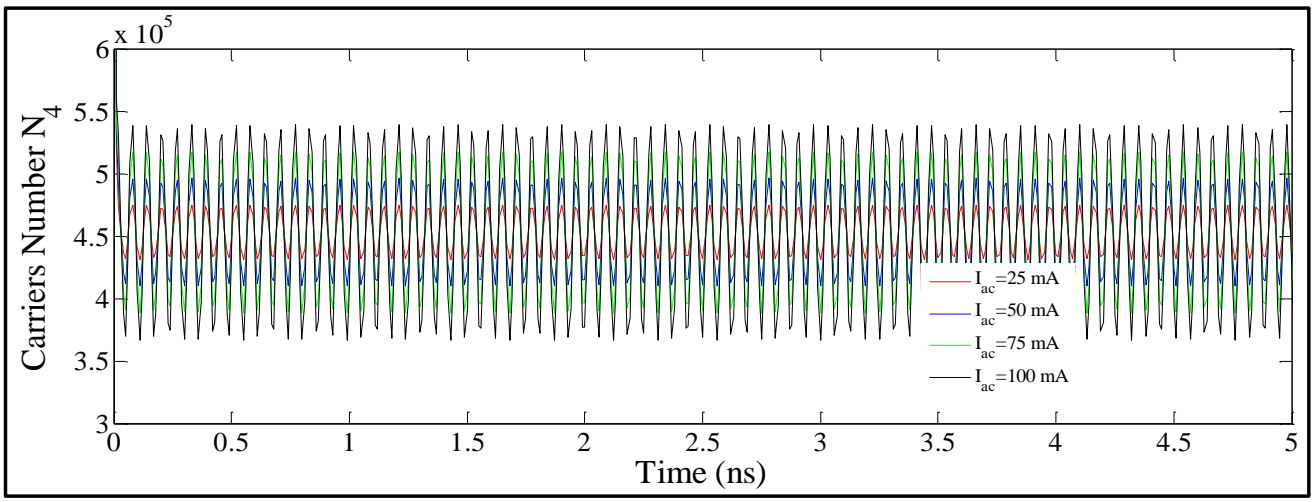

Fig (8): The time variation of the carriers $\mathrm{N} 4$ in the process current modulation with different values of the alternating current. 
University of Thi-Qar Journal Vol.13 No. 2 June 2018

Web Site: https://jutq.utq.edu.iq/index.php/main

Email: journal@jutq.utq.edu.iq

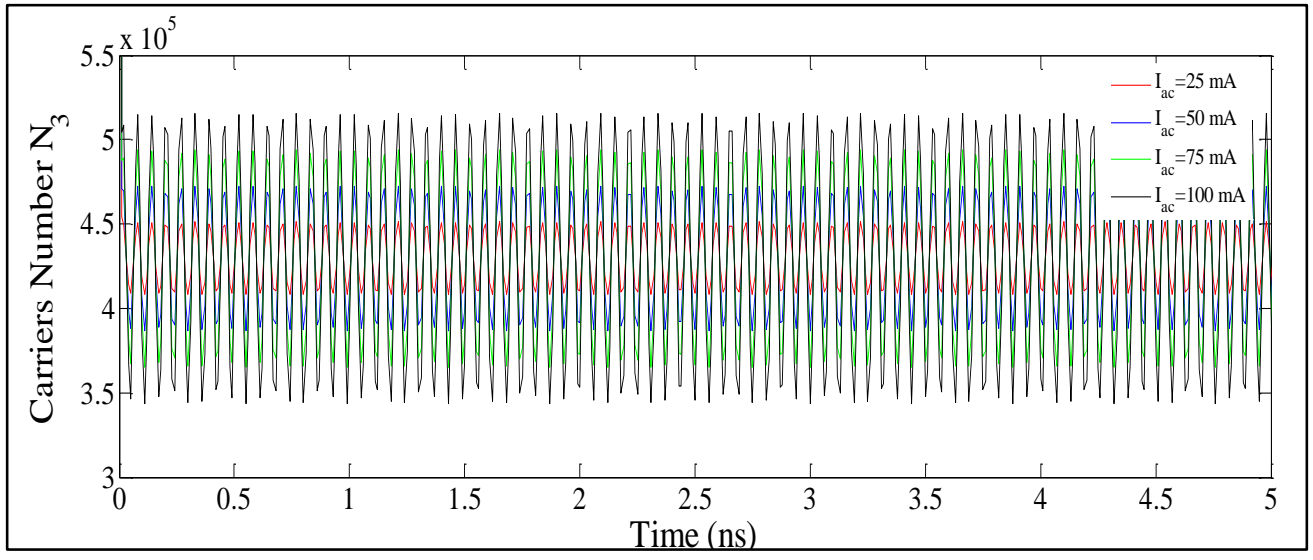

Fig (9): The time variation of the carriers N3 in the process current modulation with different values of the alternating current.

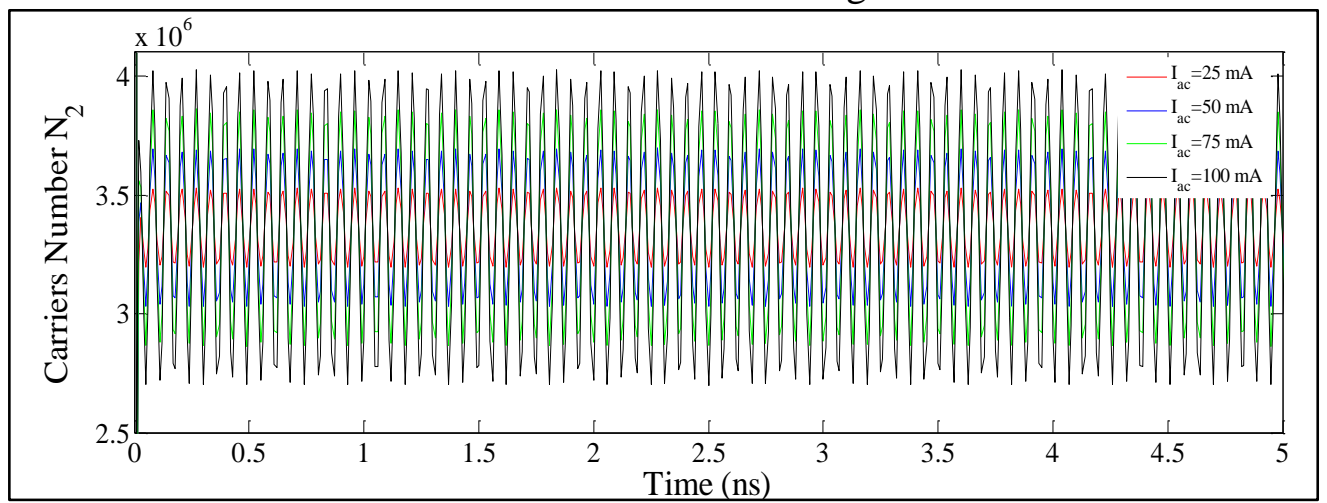

Fig (10): The time variation of the carriers N2 in the process current modulation with different values of the alternating current.

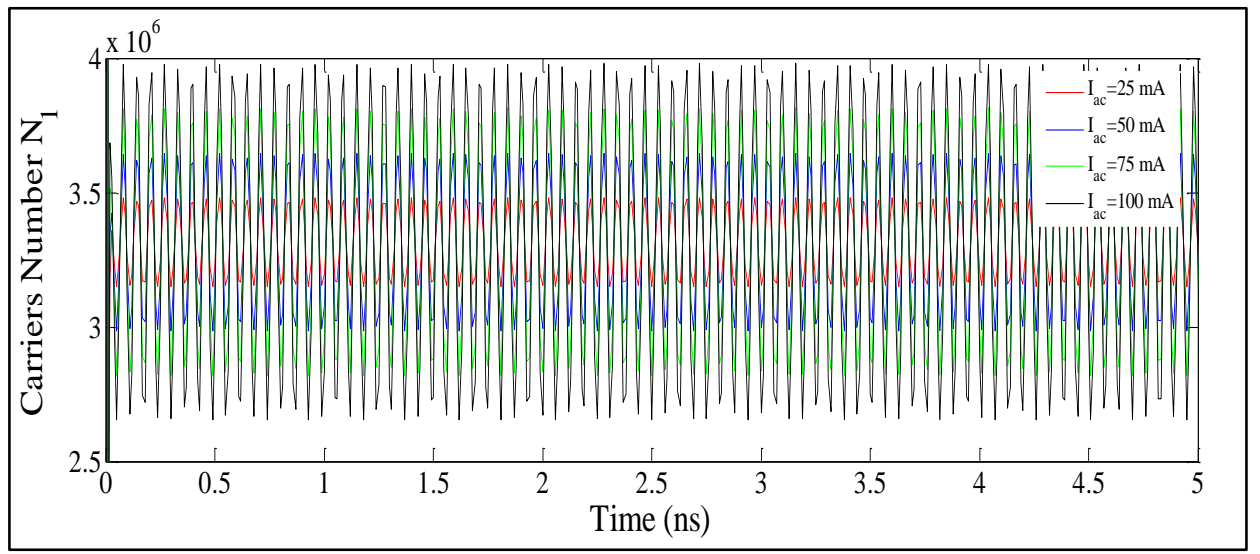


University of Thi-Qar Journal Vol.13 No. 2 June 2018

Web Site: https://jutq.utq.edu.iq/index.php/main

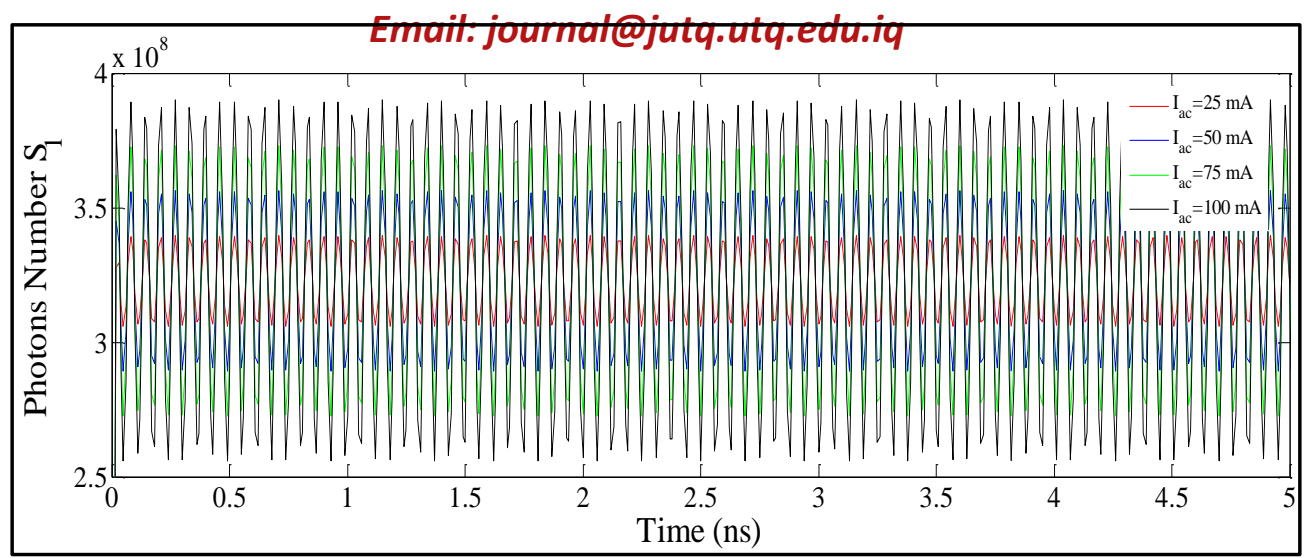

Fig (11): The time variation of the carriers N1 in the process current modulation with different values of the alternating current.

Fig (12): Time variation of photons $\mathrm{S} 1$ in the process of modulation with alternating current.

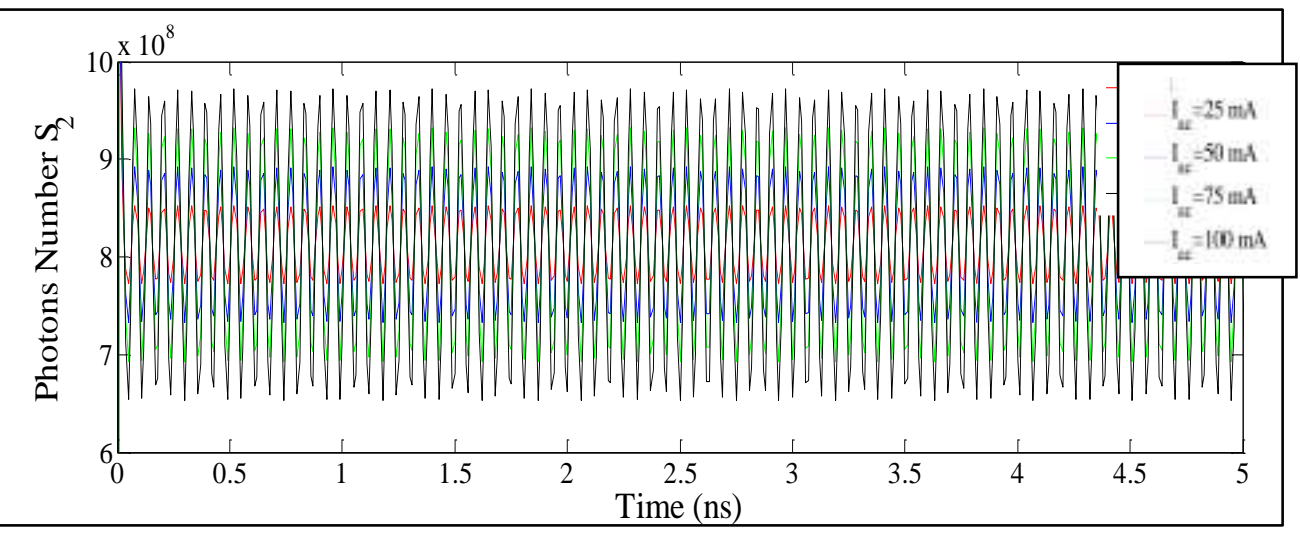

Fig (13): Time variation of photons S2 in the process of modulation with alternating current 
University of Thi-Qar Journal Vol.13 No. 2 June 2018

Web Site: https://jutq.utq.edu.iq/index.php/main

Email: journal@jutq.utq.edu.iq

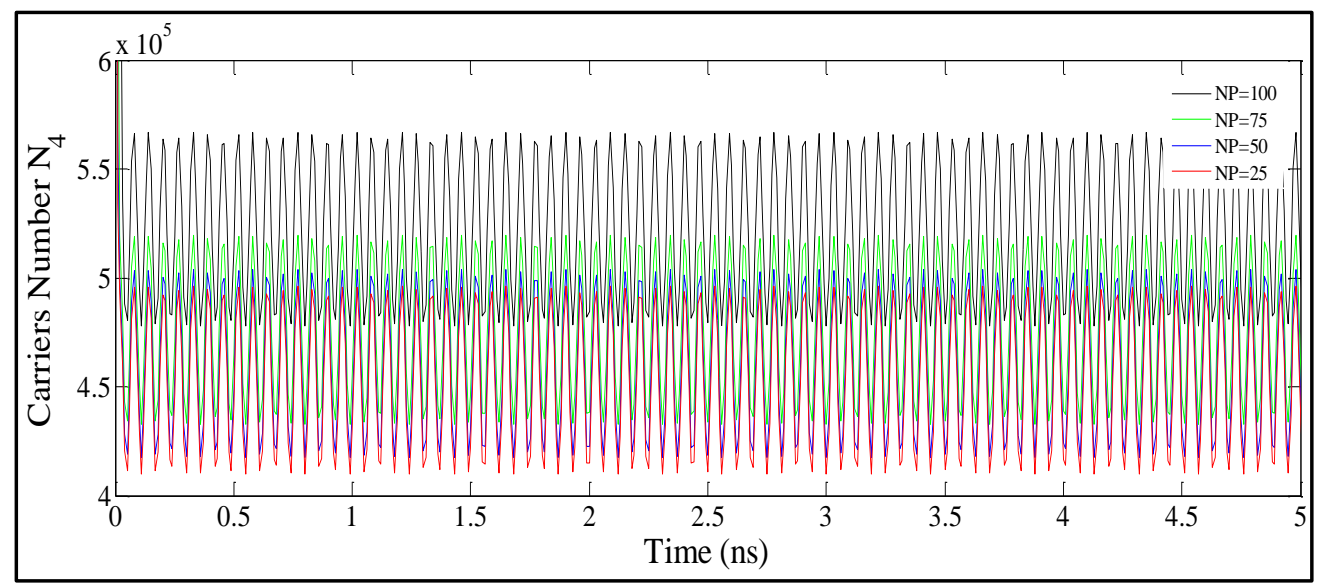

Fig (14): The time variation of the carriers N4 in the process current modulation with different values of the number of gain stages . 
University of Thi-Qar Journal Vol.13 No. 2 June 2018

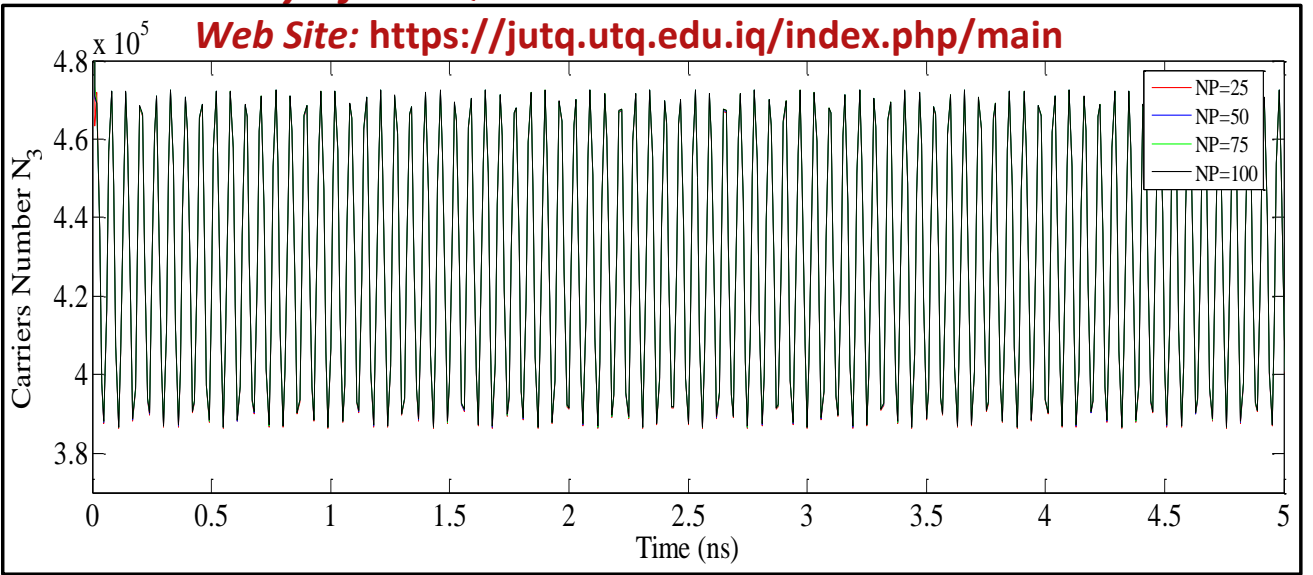

Fig (15): The time variation of the carriers N3 in the process current modulation with different values of the number of gain stages .

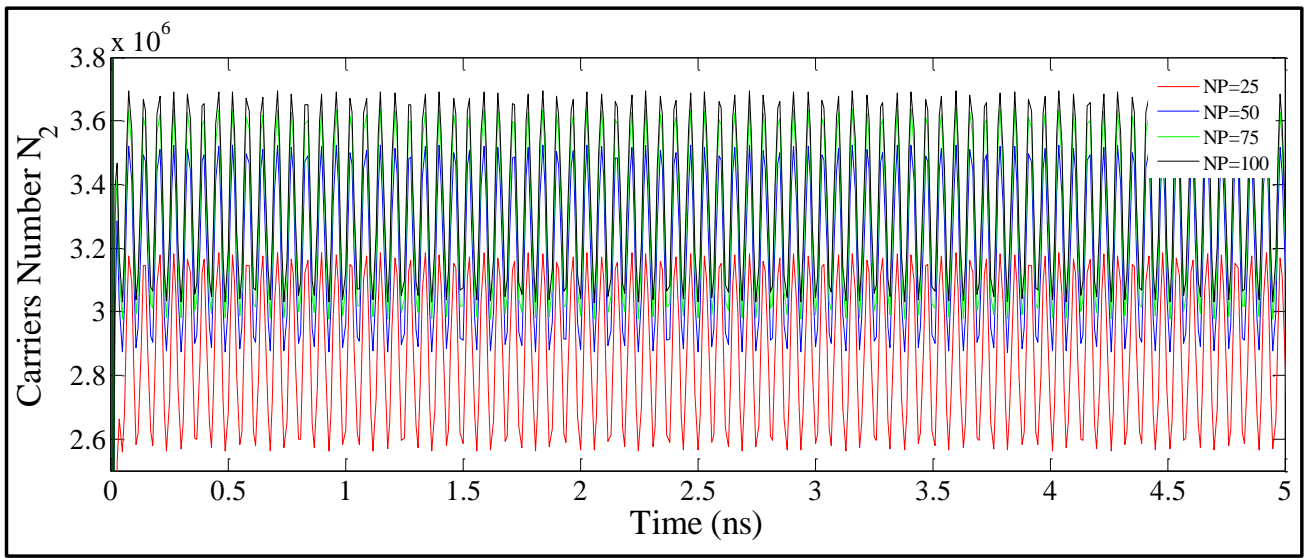

Fig (16): The time variation of the carriers N2 in the process current modulation with different values of the number of gain stages .

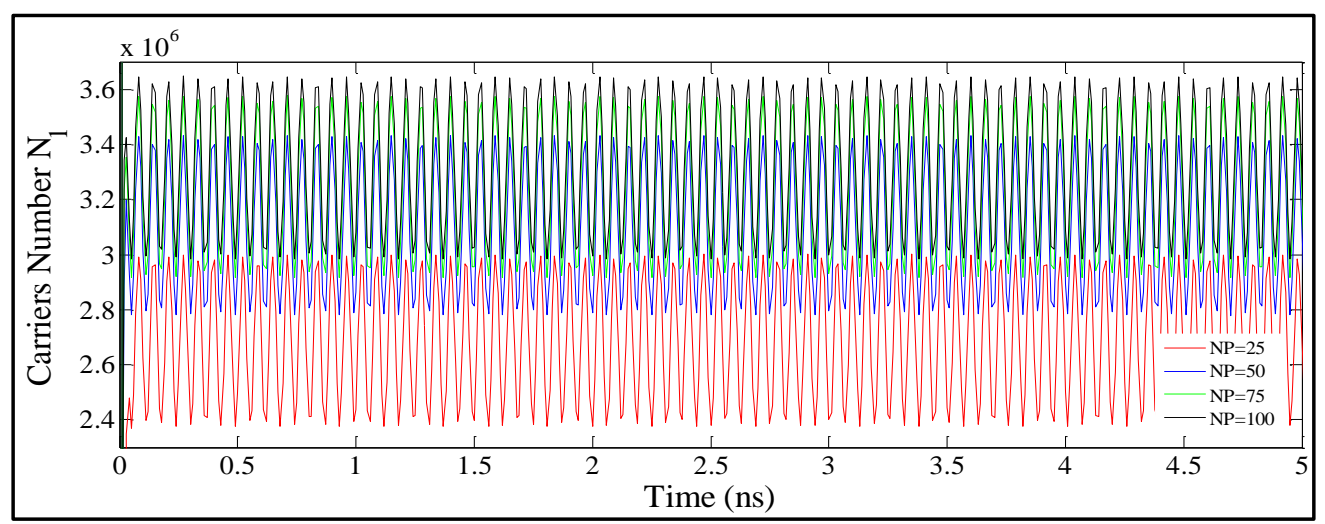

Fig (17): The time variation of the carriers N1 in the process current modulation with different values of the number gain stages . 


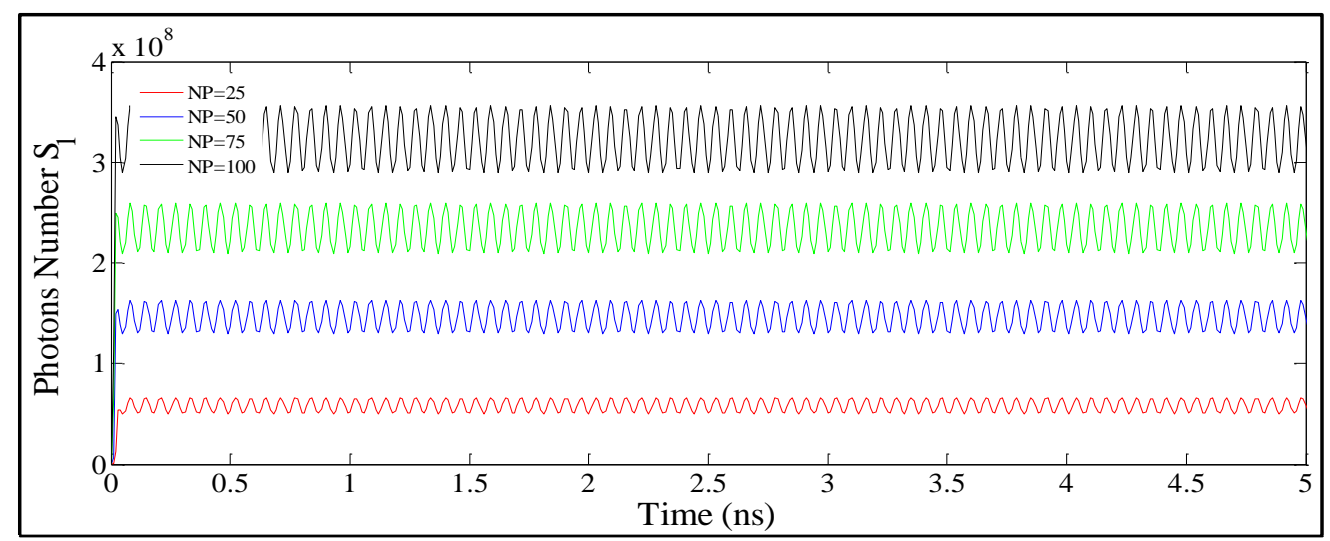

Fig (18): Time variation of photons S1 in the process of modulation with different values of number gain stag.

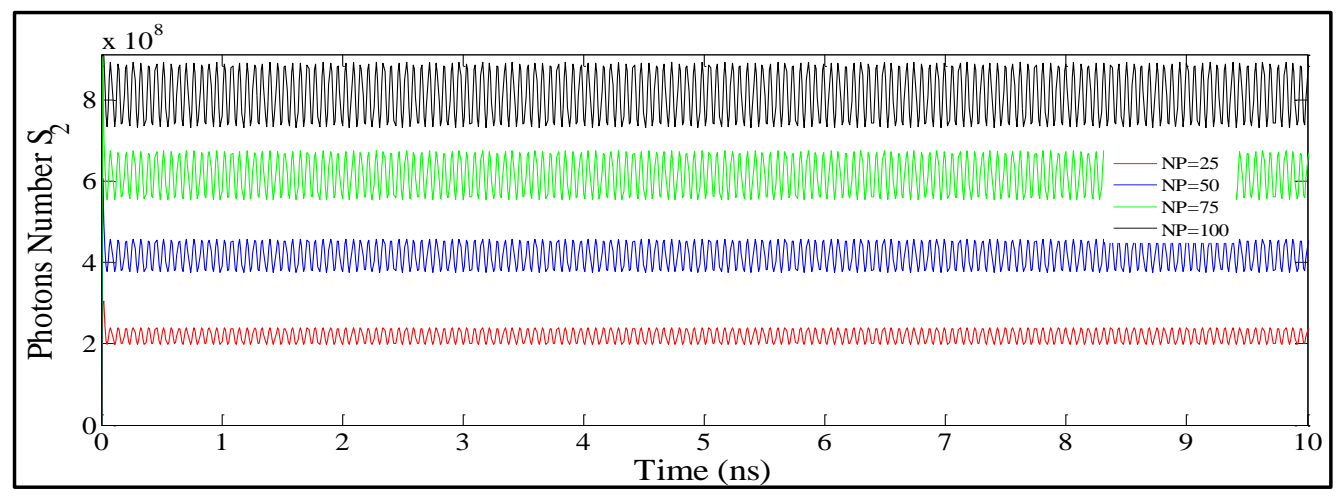

Fig (19): Time variation of photons S2 in the process of modulation with different values of number gain stages.

Fig (20): The time variation of the carriers N4 in the process current modulation with different values for the modulation frequency . 
University of Thi-Qar Journal Vol.13 No. 2 June 2018

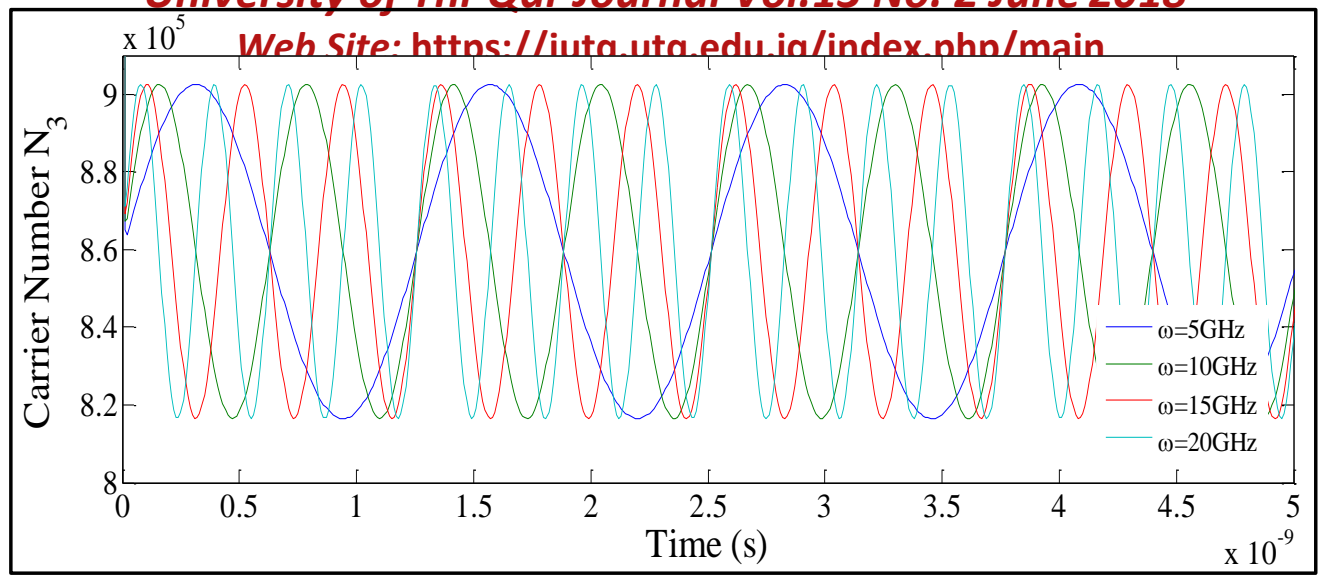

Fig (21): The time variation of the carriers N3 in the process current modulation with different values for the modulation frequency.

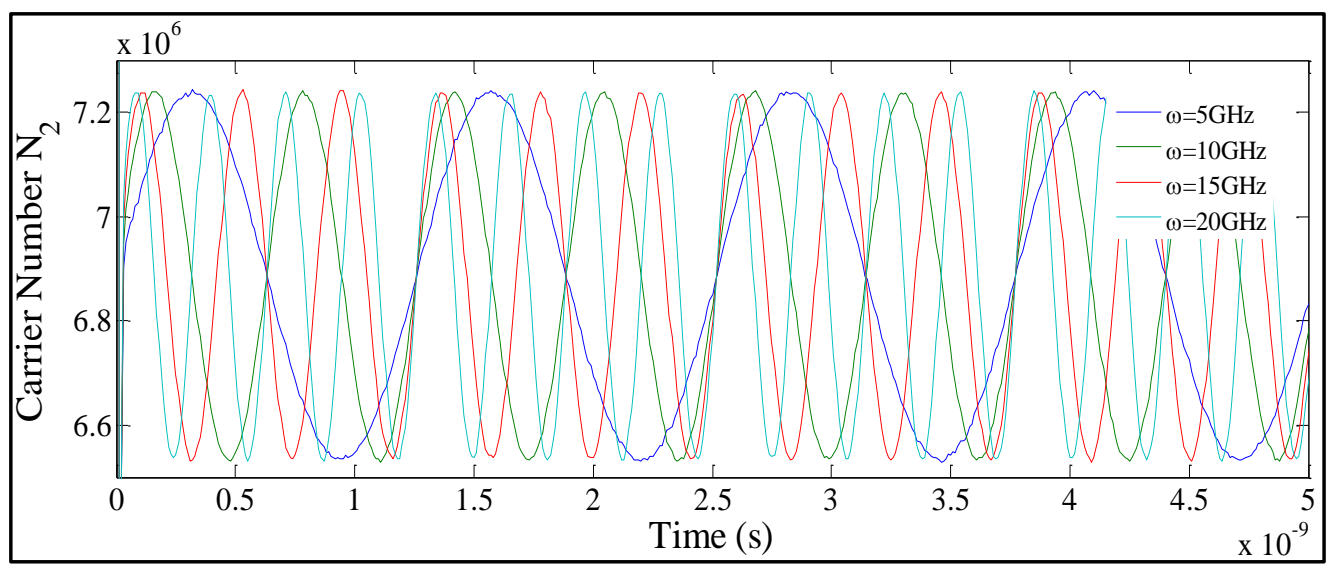


Web Site: https://jutq.utq.edu.iq/index.php/main

Email: journal@jutq.utq.edu.iq

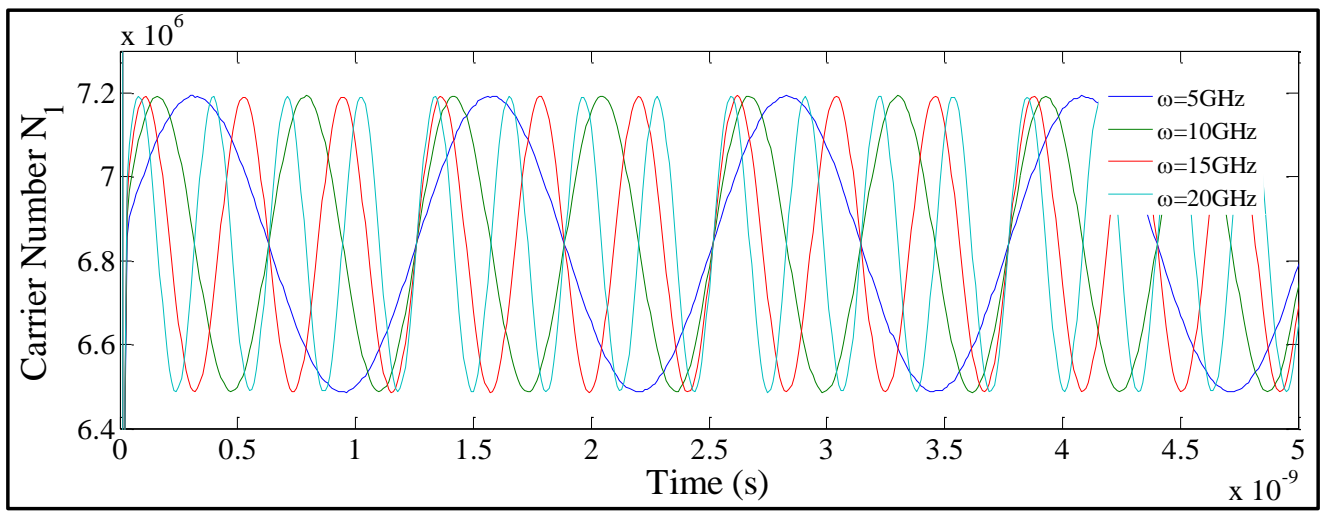

Fig (22): The time variation of the carriers N2 in the process current modulation with different values for the modulation frequency. Fig (23): The time variation of the carriers N1 in the process current modulation with different values for the modulation frequency .

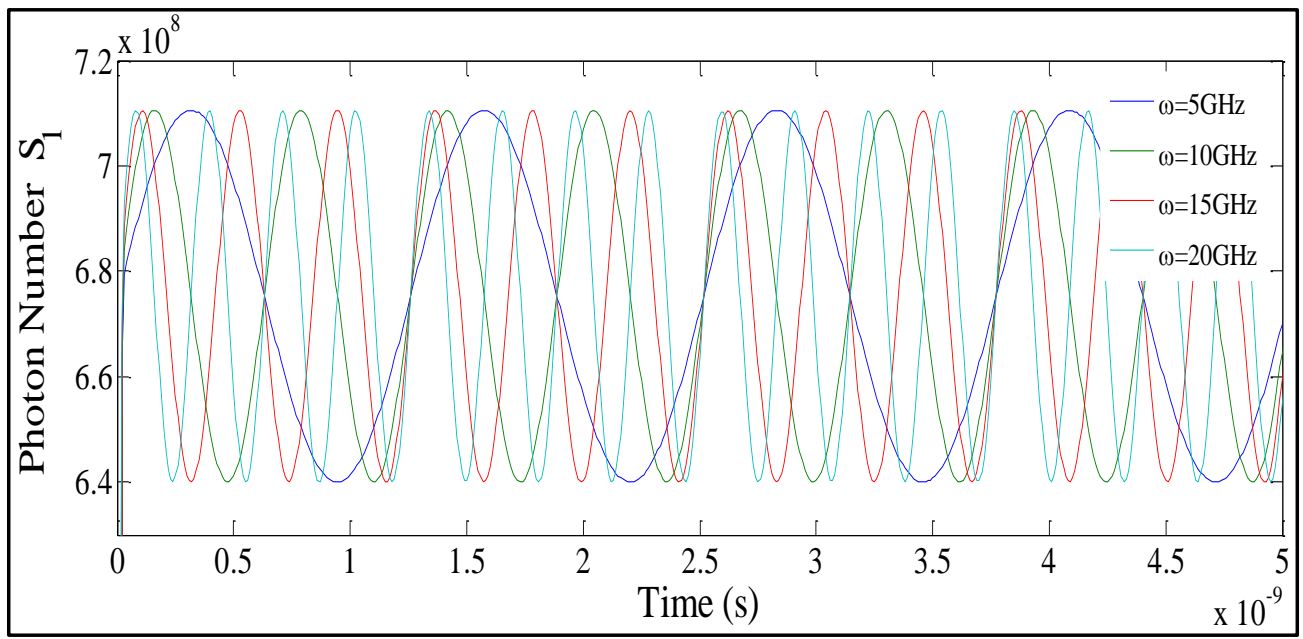

Fig (24): Time variation of photons S1 in the process of modulation with different values for the modulation frequency. 


\section{University of Thi-Qar Journal Vol.13 No. 2 June 2018 \\ Web Site: https://jutq.utq.edu.iq/index.php/main \\ Email: journal@jutq.utq.edu.iq}

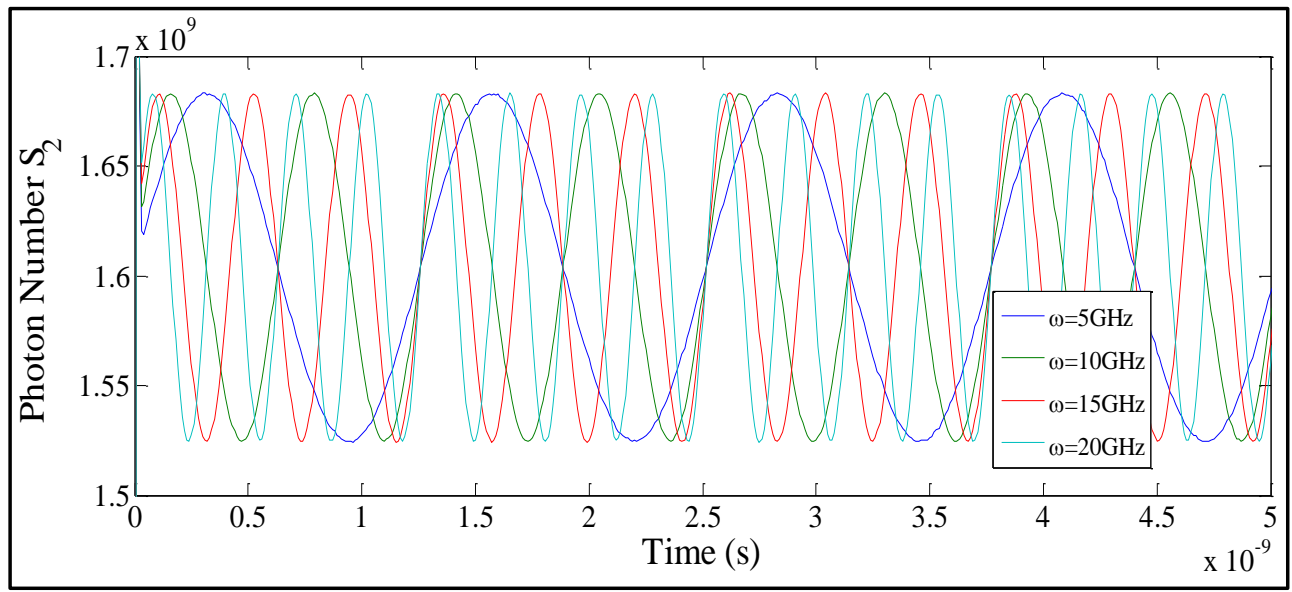

Fig (25): Time variation of photons S2 in the process of modulation with different values for the modulation frequency.

\section{Conclusions}

In this research, we studied a unique type of semiconductor laser because of its dependence on one type of carrier in its work, the electrons, So we got rid of the effect of the energy gap and changing it with temperature. This type is a dual color quantum cascade lasers that sends two wavelengths due to a two laser levels of photon production . In this study, a mathematical model was proposed to describe the movement of electrons and photons in dual color quantum cascade lasers. The model consists of six differential equations, two of these equations to describe two-wave photons, and the other four equations to describe the movement of electrons. after that an equation was used to include the injected current in the active region and we studied the effect of the number of gain region , the inclusion frequency, the continuous injection current and the alternating injection current on the distribution of electrons and photons within the active region. The results indicated a significant to increase in the number of electrons and photons with increasing both the continuous current and the number of region gain compared to the increase in their 


\section{University of Thi-Qar Journal Vol.13 No. 2 June 2018 \\ Web Site: https://jutq.utq.edu.iq/index.php/main \\ Email: journal@jutq.utq.edu.iq}

values with the increase of alternating current. One can observe the stability of the electrons distribution in the second electronic level with the increase in the region gain number, This shows that the effect of gain stage number on this region is weak. The results also indicated to a change in the electrons distribution and photons with frequency modulation changes.

\section{References}

[1]C. Cheung, P. Spencer, K. Shore, Modulation bandwidth optimisation for unipolar intersubband semiconductor lasers, IEE Proceedings-Optoelectronics 144(1) (1997) 44-47.

[2]H. Page, S. Dhillon, M. Calligaro, C. Becker, V. Ortiz, C. Sirtori, Improved CW operation of GaAs-based QC lasers: T/sub max/= $150 \mathrm{~K}$, IEEE Journal of quantum electronics 40(6) (2004) 665-672.

[3]A. Tredicucci, C. Gmachl, F. Capasso, D.L. Sivco, A multiwavelength semiconductor laser, Nature 396(6709) (1998) 350.

[4]C. Gmachl, A. Tredicucci, D.L. Sivco, A.L. Hutchinson, F. Capasso, A.Y. Cho, Bidirectional semiconductor laser, Science 286(5440) (1999) 749-752.

[5]N. Owschimikow, C. Gmachl, A. Belyanin, V. Kocharovsky, D.L. Sivco, R. Colombelli, F. Capasso, A.Y. Cho, Resonant second-order nonlinear optical processes in quantum cascade lasers, Physical review letters 90(4) (2003) 043902.

[6]J.-Y. Bengloan, A. De Rossi, V. Ortiz, X. Marcadet, M. Calligaro, I. Maurin, C. Sirtori, Intracavity sum-frequency generation in GaAs quantum cascade lasers, Applied physics letters 84(12) (2004) 2019-2021.

[7]J. Bai, D.S. Citrin, Optical and transport characteristics of quantum-cascade lasers with optimized second-harmonic generation, IEEE journal of quantum electronics 43(5) (2007) 391-398.

[8]A. Rostami, H.B.A. Nejad, H.R. Saghai, M. Noori, Linear frequencydoubling in dual Mid-IR-wavelength quantum cascade laser active region, Superlattices and Microstructures 45(3) (2009) 134-142.

[9]A. Rostami, B. Mirzaei, H. Baghban, Two-wavelength THz quantum cascade laser with highly enhanced temperature characteristics, Communications and Photonics Conference and Exhibition (ACP), 2009 Asia, IEEE, 2009, pp. 1-8.

[10]N. Mustafa, L. Pesquera, C. Cheung, K. Shore, Terahertz bandwidth prediction for amplitude modulation response of unipolar intersubband semiconductor lasers, IEEE Photonics Technology Letters 11(5) (1999) 527529.

[11]C. Cheung, K. Shore, Self-consistent analysis of the dc modulation response of unipolar semiconductor lasers, Journal of Modern Optics 45(6) (1998) 12191229. 
University of Thi-Qar Journal Vol.13 No. 2 June 2018

Web Site: https://jutq.utq.edu.iq/index.php/main

Email: journal@jutq.utq.edu.iq

[12]A. Rostami, H. Rasooli, H. Baghban, Terahertz technology: fundamentals and applications, Springer Science \& Business Media2010.

[13]T. Gensty, W. Elsäßer, Semiclassical model for the relative intensity noise of intersubband quantum cascade lasers, Optics Communications 256(1) (2005) 171-183. 